NBER WORKING PAPER SERIES

\title{
OWNER-OCCUPIED HOUSING AS A HEDGE AGAINST RENT RISK
}

\author{
Todd Sinai \\ Nicholas S. Souleles \\ Working Paper 9462 \\ http://www.nber.org/papers/w9462
NATIONAL BUREAU OF ECONOMIC RESEARCH
1050 Massachusetts Avenue
Cambridge, MA 02138
January 2003

We are grateful to Ed Glaeser, Joe Gyourko, Matt Kahn, Chris Mayer, Robert Shiller, Jonathan Skinner, and participants in seminars at the AEA/AREUEA 2001 annual meetings, NBER, Syracuse University, University of Wisconsin, University of British Columbia, UC Berkeley, and Wharton for their helpful comments and suggestions. James Knight-Dominick provided excellent research assistance. Sinai acknowledges financial support from the Ballard Scholars Program of the Zell/Lurie Real Estate Center at Wharton. Souleles acknowledges financial support from the Rodney L. White Center for Financial Research. The views expressed herein are those of the authors and not necessarily those of the National Bureau of Economic Research.

(C)2003 by Todd Sinai and Nicholas Souleles. All rights reserved. Short sections of text not to exceed two paragraphs, may be quoted without explicit permission provided that full credit including notice, is given to the source. 
Owner-Occupied Housing as a Hedge Against Rent Risk

Todd Sinai and Nicholas Souleles

NBER Working Paper No. 9462

January 2003

JEL No. R21, E21, G11, G12, J14

\section{$\underline{\text { ABSTRACT }}$}

Many people assume that the most significant risk in the housing market is that homeowners are exposed to fluctuations in house values. However, homeownership also provides a hedge against fluctuations in future rent payments. This paper finds that, even though house price risk endogenously increases with rent risk, the latter empirically dominates for most households - so housing market risk actually increases homeownership rates and house prices. Further, the net effect of rent risk on the demand for homeownership increases with a household's expected length of stay in its home, as the cumulative rent volatility rises and the discounted house price risk falls. Using CPS data, the difference in the probability of homeownership between households with long and short expected lengths of stay is 2.9 to 5.4 percentage points greater in high rent variance places than low rent variance places. The sensitivity to rent risk is greatest for households that devote a larger share of their budgets to housing, and thus face a bigger gamble. Similarly, the elderly who live in high rent variance places are more likely to own their own homes, and their probability of homeownership falls faster with age (as their horizon shortens). This aversion to rent risk might help explain why older households do not consume much of their housing wealth. Finally, we find that house prices capitalize not only expected future rents, but also the associated rent risk premia. At the MSA level, a one standard deviation increase in rent variance increases the house price-to-rent ratio by 2 to 4 percent.

\section{Todd Sinai}

Wharton School

University of Pennsylvania

308 Lauder-Fischer Hall

256 South $37^{\text {th }}$ Street

Philadelphia, PA 19104-6330

and NBER

sinai@wharton.upenn.edu
Nicholas S. Souleles

Wharton School

University of Pennsylvania 2300 Steinberg Hall - Dietrich Hall

Philadelphia, PA 19104-6367

and NBER

souleles@wharton.upenn.edu 
According to the 2000 Decennial Census, 68 percent of U.S. households own the house they live in. Those households commit a substantial portion of their net worth to their house, 27 percent on average [Poterba and Samwick (1997)]. For households with heads aged 65 and over, housing wealth comprises 45 percent of their non-Social Security wealth. Conventional wisdom holds that this substantial, undiversified exposure to real estate assets makes home owning quite risky, since fluctuations in house prices can have a sizeable effect on households' net worth.

However, the alternative to home owning - namely, renting - is also risky. In particular, a renter is subject to periodic rent adjustments whereas a homeowner can lock in the cost of future housing services. In essence, bundled into the house purchase is a hedge against rent fluctuations. Since housing costs are the largest component of most households' budgets, representing on average about a third of annual income, and market rents can be quite volatile with an average standard deviation of 2.9 percentage points per year, the ability to lock in the cost of housing services may be valuable. Nonetheless, long-term rent contracts are rare in the U.S. Genesove (1999) reports that 97.7 percent of all residential leases are for terms of one year or less. In addition, one cannot purchase a "rent swap" to exchange variable rents for fixed rents. ${ }^{1}$ Thus the only way in practice to hedge against uncertain annual housing costs is to own a house instead of renting it.

This rent hedging benefit of owner-occupied housing must of course be compared to its asset price risk, which itself endogenously increases with rent risk. If the rent risk on balance dominates the asset price risk, a household should be willing to pay a premium above the value of the service flow from a residence in order to own it rather than rent it. Depending on the elasticity

\footnotetext{
${ }^{1}$ We can only speculate as to why more rent-hedging contracts do not exist. One possibility is that the contracting is quite difficult. Presumably a swap would have to terminate if one party moved. But if rents fell and the renter owed a sufficient amount of money on his half of the swap, he would simply move and exit the contract. In addition, it may be expensive to put such a swap in place for a long term.
} 
of supply of owned housing units, this hedging demand for home owning may show up in a higher homeownership rate, higher house prices, or both.

After modeling the joint effect of both rent risk and house price risk on the tenure decision and house prices, we find that rent risk empirically dominates for most households, in the sense that an increase in rent volatility on net increases the demand for homeownership. Hence housing market risk can actually increase homeownership rates and house prices. By contrast, the previous literature on housing tenure choice has largely ignored the risks associated with renting. For example, most studies compute a deterministic user cost of housing. ${ }^{2}$ On the other hand, some recent contributions to the portfolio choice literature have modeled the demand for owning risky real estate assets, but they generally neglect the tenure decision and instead focus on various costs of the asset price risk from home owning, for example the resulting distortions to owners' financial portfolio allocations [Brueckner (1997), Goetzmann (1993), Flavin and Yamashita (1998), and Fratantoni (1997)] or to their saving and consumption behavior [Engelhardt (1996), Skinner (1989)]. ${ }^{3}$ Hence this paper can be seen as extending the existing literatures to account for a central but understudied element of household risk management. ${ }^{4}$

\footnotetext{
${ }^{2}$ The traditional user cost literature, e.g. Rosen (1979), Poterba (1984), and Hendershott and Slemrod (1983), estimates housing demand as a function of just expected returns on housing.

${ }^{3}$ Skinner (1989) and Summers (1983) consider the asset price risk of the house, but not the value of housing as a hedge against rent fluctuations. Davidoff (2001) measures asset price risk by how much house prices covary with labor income but is primarily concerned with its effect on the amount of housing purchased in a portfolio context. He assumes exogenous house prices and does not consider the tradeoff with rent risk. Only Rosen et al (1984) and Henderson and Ioannides (1983) consider rent risk. In a time series study, Rosen et al find that one predictor of the aggregate homeownership rate is the difference between the unforecastable volatility of the user cost of homeownership and rents. They assume that rental housing and owner-occupied housing are independent goods, so they do not allow for an endogenous relation between house prices and rent. In Henderson and Ioannides, the rent risk is to the landlord, not the tenant. In their model, the tenant may not properly care for the property. This incentive compatibility problem raises the average rent for renters but does not involve rent volatility.

${ }^{4}$ Other papers investigate alternative sources of household risk. Cocco (2000) and Haurin (1991) investigate the effects of income risk on housing portfolio choice. Cocco also includes interest rate risk, in a parameterized structural model of housing investment, but he rules out the possibility of renting. Campbell and Cocco (2001) simulate the covariance of income, interest rates, and house prices as a way of explaining whether people finance their house with fixed or floating rate debt. However, their financing decision does not involve the tradeoff between rent expenditures and asset price risk. Other work emphasizes the negative effects of depressed house prices and housing equity on household mobility [Chan (2001), Genesove and Mayer (1997), Stein (1995)].
} 
We begin with a stylized model of tenure choice in the presence of both rent risk and house price risk when house prices endogenously capitalize the discounted value of future rents. Holding the house price fixed, the demand for home owning increases with rent risk. However, more rent risk also leads to greater house price risk. We find that the impact of rent risk on a household increases with its expected length of stay in its residence, and that for a household that expects to stay in its residence beyond a few years the risk of renting can dominate the asset price risk of owning. This result occurs because rent fluctuations affect renters every year whereas the asset price risk for owners is realized only at the end of their stay in their house, when they sell. If the realization of the house price is sufficiently discounted, either because the homeowner expects to remain in the house for a long enough time or her discount rate is sufficiently high, the rent risks dominate the discounted house price risk, increasing demand for home owning relative to renting. In that case, households with longer expected lengths of stay that live in markets with larger rent variances should have higher probabilities of homeownership, and houses in those markets should exhibit higher prices relative to rents.

We test these implications using both Metropolitan Statistical Area (MSA) level and household level data from the Current Population Survey matched to MSA level rent data. Overall, we find that the rent hedging benefit of homeownership substantially increases the demand for owner-occupied housing, for the population as a whole and especially for the elderly, above and beyond other factors influencing homeownership. To isolate the effect of rent risk from the many other reasons why people might own their houses, we control for both MSA and individual heterogeneity, and examine how the probability of homeownership differs for households with varying expected lengths of stay in markets with different rent variances. ${ }^{5}$ For example, in the

\footnotetext{
${ }^{5}$ For example, homeownership can vary with income, demographics and tax benefits [Rosen (1979)], inflation [Summers (1981)], and the agency costs of renting [Henderson and Ioannides (1983)].
} 
household level data, we separately control for the rent variance in households' MSAs and for their expected length of stay in their residences (which also controls for transactions costs in buying and selling houses, among other factors), and then focus on the interaction of the rent variance with the expected length of stay. We find that the difference in the likelihood of homeownership for a household that is above the median in expected length of stay and a below-the-median household is up to 5.4 percentage points greater in high rent variance MSAs than in MSAs with lower rent variance. We also find evidence that the sensitivity to rent risk is pronounced for households that face a large housing gamble, in that rents in their MSA comprise a large portion of their annual income. Among such households, those with long expected lengths of stay are the most responsive to rent variance, having a 6.1 percentage point higher probability of homeownership relative to the other households if they live in a MSA with high rent risk.

The rent hedging benefit of owning is particularly pronounced for the elderly. All else equal, a household with a head who is 60 years old is 10.1 percentage points more likely to own its home if it is in the top quartile of rent variance. Moreover, the probability of homeownership declines most steeply with age in high rent variance markets. As the end of life approaches, the rent hedge becomes less valuable as the number of periods for which a home owning household expects to be insured against rent risk falls. Thus the rent hedging benefit of homeownership may provide a partial explanation for the failure of the elderly to transit out of homeownership as early as traditional life-cycle models predict [Venti and Wise (2000); Megbolugbe, et al (1997)]. ${ }^{6}$

In addition to homeownership rates, the extra demand for home owning due to rent risk can be capitalized into house prices. We measure the additional value to owning rather than renting by comparing the house price relative to the flow value of housing services, i.e. rent. We find that

\footnotetext{
${ }^{6}$ These findings underscore the need for viable reverse mortgage markets to enable households to avoid rent risk by continuing to own their houses while annuitizing their housing wealth. To date, these markets have not been particularly successful [Caplin (2001)].
} 
house prices incorporate not only expected future rents, but also a premium for avoiding rent risk. This result is consistent with asset-pricing models of other, financial assets. At the MSA level, a one standard deviation increase in rent variance raises the average price-to-rent ratio in a market from 15.7 to as much as 16.3. Holding rents constant, this corresponds to a 2 to 4 percent increase in house prices.

The remainder of this paper proceeds as follows. In section I, we present a simplified model of tenure choice in the presence of both rent risk and house price risk. Section II describes our data sources and variable construction. The empirical methodology and results are reported in section III. Section IV briefly concludes.

\section{A simple model of the hedging benefit of owner-occupied housing}

This section presents a stylized model of tenure choice in which the annual cost of securing housing services is uncertain. The model is simplified in order to highlight the key tradeoffs between the risks of renting versus those of home owning that we will test in our empirical work. In particular, rent fluctuations are generated by exogenous shocks to the housing market. Renters' leases have a one-year term, so the price renters must pay for a given quantity of housing services can vary from year to year. On the other hand, homeowners fix the annual cost of obtaining housing services by purchasing their houses outright. However, at the end of their stay in the house, homeowners realize a capital gain or loss, whereas renters face no asset price risk.

House prices endogenously capitalize the discounted value of future rents, so they fluctuate with the housing market shocks as well. The volatility of house prices depends on the persistence of the rent shocks, with more persistent shocks leading to larger house price volatility. The relative importance of rent risk versus house price risk depends on this persistence as well as the 
households' expected length of stay (horizon) in their residence. A household that expects to stay longer would be exposed to more rent shocks as a renter and the asset risk from home owning would occur later and thus would be more greatly discounted. Hence the demand for homeownership will rise, ceteris paribus, with rent risk, the household's expected horizon, and the interaction of horizon with the rent risk.

To isolate the effect of rent risk we abstract from other features of housing markets that do not directly bear on the dynamic relationship between house prices and rent risk. The previous literature on tenure choice has focused on deterministic models of the user cost, for example identifying the effects of taxes. The stochastic factors at issue here apply above and beyond the previously studied features of the tenure decision.

Consider a risk-averse household with an N-year horizon for housing services, with the years labeled $t=0,1, \ldots, \mathrm{N}-1$. The household has already decided on the optimal quantity of housing space it wants to consume each year, for simplicity assumed to be constant. The household's goal is to maximize the expected utility of its after-housing wealth, or equivalently to minimize the risk-adjusted cost of securing its desired housing services. For convenience we assume that rental units and owner-occupied houses provide the same flow of housing services. ${ }^{7}$

To begin with, suppose the household is choosing between renting for all $\mathrm{N}$ years, or buying a house in year 0 and then selling it after $\mathrm{N}$ years. ${ }^{8}$ The current real rent $\mathrm{r}_{0}$ and house price $\mathrm{P}_{0}$ are observable, but the future rents $\mathrm{r}_{1}$ to $\mathrm{r}_{\mathrm{N}-1}$ and terminal house sale price $\mathrm{P}_{\mathrm{N}}$ are stochastic.

\footnotetext{
${ }^{7}$ Equivalently, the household can be thought of as choosing between owning and renting the same house. The comparative statics below can be generalized to allow the services from the owner-occupied house to exceed those from renting (perhaps due to agency problems). In practice rent risk might also reduce the desired size of rental space (the intensive margin). While this effect is consistent with the hedging motives under investigation, it would make it more difficult to find an effect on the rent versus own (extensive) margin analyzed empirically. Hence our results will provide a lower bound for the full importance of the rent hedging motive.

${ }^{8}$ Below we show that in our context, if the household buys a house, it will generally want to buy as early as possible. Hence other options, e.g., renting for one year and then buying, will not be relevant. For convenience below, the sale is assumed to take place at the beginning of year $\mathrm{N}$.
} 
Accordingly the household's goal is to minimize the risk-adjusted discounted value of its housing outlays. ${ }^{9}$ For simplicity we abstract from other factors that affect homeownership and rental costs, such as the tax treatment of homeownership. Such factors may affect the relative cost of owning and renting, but they will not qualitatively change the comparative statics at issue here regarding the effects of increases in the riskiness of rent. ${ }^{10}$

The discounted cost of renting is $\mathrm{C}_{\mathrm{r}}=\mathrm{r}_{0}+\delta \mathrm{r}_{1}+\ldots+\delta^{\mathrm{N}-1} \mathrm{r}_{\mathrm{N}-1}$. The discount factor $\delta$ reflects the opportunity cost of funds, as in the traditional definition of user cost. The risk associated with renting can be measured by the risk premium $\pi\left(\mathrm{C}_{\mathrm{r}}\right)$ that would leave the household indifferent between $\mathrm{C}_{\mathrm{r}}$, which is stochastic, and its expected value. This risk premium depends on the stochastic process for rent. Suppose rents follow a general AR(1) process with drift $\mu: r_{t}=\mu+\rho r_{t-1}$ $+\eta_{\mathrm{t}}$, where persistence $\rho \in[0,1]$ and $\eta$ is distributed $\operatorname{IID}\left(0, \sigma_{\mathrm{r}}^{2}\right){ }^{11}$ The resulting risk premium can be approximated by

$$
\pi\left(C_{r}\right) \approx 1 / 2 \alpha \sigma_{r}^{2}\left[\left(\delta+\rho \delta^{2}+\ldots+\rho^{N-2} \delta^{N-1}\right)^{2}+\left(\delta^{2}+\rho \delta^{3}+\ldots+\rho^{N-3} \delta^{N-1}\right)^{2}+\ldots+\left(\delta^{N-1}\right)^{2}\right]
$$

where $\alpha$ measures risk aversion. ${ }^{12}$ To interpret this risk premium, note that the square brackets include $\mathrm{N}-1$ terms in parentheses that correspond to the $\mathrm{N}-1$ rent innovations $\eta_{1}$ to $\eta_{\mathrm{N}-1}$, with the later innovations discounted more heavily. For instance, if the rent shocks are IID, with $\rho=0$, then

\footnotetext{
${ }^{9}$ We have intentionally abstracted from capital market imperfections (e.g., liquidity constraints) leading households to want to smooth their year-to-year housing expenditures. While we believe this may be an important extension, modeling it would be unnecessarily complex and would probably only strengthen the results here.

${ }^{10}$ Since interest rates are nearly constant across the country and depreciation schedules are set at the federal level, variation in them over time will not affect our empirical methodology. Property taxes are incorporated in rents and thus do not differ between owners and renters. Maintenance costs are deferrable for owners and are incorporated into rents for renters and thus show up in our rent variance measure. Berkovec and Fullerton (1992) argue that taxes provide some risk sharing between homeowners and the government. We will control for tax regime changes over time in the estimation but do not want to unduly complicate the model.

${ }^{11}$ We take the rent process as given, without modeling its underlying determinants, for example, shocks to demand for housing space. Analogous to term structure models of long versus short maturity bonds, the process for one period (short) rental rates is the input into the model.

${ }^{12}$ As usual the quantitative results for risk premia are in general based on local approximations, but for exponential preferences they hold exactly.
} 
the risk premium is proportional to $\left[\delta^{2}+\delta^{4}+\ldots+\delta^{(\mathrm{N}-1) 2}\right] \sigma_{r}^{2}$. If the shocks are persistent, $\rho>0$, then each innovation $\eta_{\mathrm{t}}$ continues to augment the risk premium in subsequent periods, in proportion to its persistence, $\rho$. Thus the risk premium for renting, $\pi\left(C_{r}\right)$, is increasing in $\sigma_{r}^{2}$ and in the horizon N. Since home owning avoids the N-1 rent risks, $\pi\left(C_{r}\right)$ will appear below as part of the net benefit of owning, which is the alternative to renting.

The discounted cost of owning is $\mathrm{Co}=\mathrm{P}_{0}-\delta^{\mathrm{N}} \mathrm{P}_{\mathrm{N}}$. While owning avoids the N-1 risks associated with renting, it introduces the discounted house price risk due to $\mathrm{P}_{\mathrm{N}}$. The associated risk premium is denoted by $\pi(\mathrm{Co})$. Although a full general equilibrium analysis of asset prices is beyond the scope of this paper, the house price would generally capitalize the associated rental payments and therefore $\pi(\mathrm{Co})$ would also be an increasing function of the rent variance, $\sigma^{2}$, ceteris paribus. $\pi(\mathrm{Co})$ would also be a decreasing function of $\mathrm{N}$, ceteris paribus, because the later the house price risk is realized, the more heavily it will be discounted. ${ }^{13}$

The net risk premium associated with renting, $\pi\left(\mathrm{C}_{\mathrm{r}}\right)-\pi(\mathrm{Co})$, would therefore be proportional to $\sigma_{\mathrm{r}}^{2}$. The sign of this net premium determines whether renting is on balance riskier than owning. If the sign is positive, then renting is riskier and the hedging demand for owning will increase with $\sigma_{r}^{2}$, ceteris paribus. If the sign is negative, the demand for owning would decrease with $\sigma_{\mathrm{r}}^{2}$. In either case, an increase in the household's horizon, $\mathrm{N}$, would increase the demand for owning, ceteris paribus. A longer horizon increases the number of rent risks, and more heavily discounts the asset price risk of owning, increasing the net risk premium.

\footnotetext{
${ }^{13}$ In the presence of transactions costs associated with selling a house, the probability of home owning will further increase in N. A household with a shorter horizon in a given location will be less likely to own, in order to avoid the fixed cost. In our empirical work below, we will include a measure of expected horizon $\mathrm{N}$ as a separate control variable to control for all horizon effects, including the number of rent risks incurred and any fixed costs.
} 
Importantly, the net risk premium is proportional to $\sigma_{\mathrm{r}}^{2}$ times an increasing function of $\mathrm{N}$. Hence the effect of increasing the horizon (higher $\mathrm{N}$ ) rises with $\sigma_{\mathrm{r}}^{2}$, the magnitude of each rent risk; and the effect of larger rent risk (higher $\sigma_{\mathrm{r}}^{2}$ ) increases with the horizon. Households with long horizons are exposed to more of the rent shocks, which are each proportional to $\sigma_{\mathrm{r}}^{2}$, and discount more heavily the asset price risk, which is also proportional to $\sigma_{\mathrm{r}}^{2}$. For households with a sufficiently long horizon, the net risk premium will be positive. Greater rent variance therefore drives them towards owning. Households with shorter horizons are exposed to fewer rent shocks and discount the asset price risk less, so the net risk premium is smaller, in some cases negative.

For illustration, consider an example with a horizon of $\mathrm{N}=3$. Suppose that in equilibrium house prices are endogenously determined such that households are indifferent between owning and renting, so that both owned and rented housing units are occupied. In this case one can show that the equilibrium price-to-rent differential

$$
\begin{aligned}
& \mathrm{P}_{0}-\mathrm{r}_{0}= \\
& \left(\mu /(1-\delta)+\mathrm{r}_{0} \rho\right) \delta /(1-\delta \rho)+1 / 2 \alpha \sigma_{\mathrm{r}}^{2}\left[\left(\delta+\delta^{2} \rho\right)^{2}+\delta^{4}-\delta^{6}\left(1+\rho^{2}+\rho^{4}\right) /(1-\delta \rho)^{2}\right] /\left(1-\delta^{3}\right) .
\end{aligned}
$$

To interpret this result consider again IID rent shocks, with $\rho=0$. Then (2) implies that $\mathrm{P}_{0}-\mathrm{r}_{0}=\mu \delta /(1-\delta)+1 / 2 \alpha \sigma_{\mathrm{r}}^{2}\left[\left(\delta^{2}+\delta^{4}-\delta^{6}\right) /\left(1-\delta^{3}\right)\right]$. The first term is the present value of the expected future rent payments, since $\mathrm{E}_{0} \mathrm{r}_{\mathrm{t}}=\mu$ in the IID case. If the rent payments are deterministic $\left(\sigma_{r}^{2}=0\right)$ or if households are risk neutral $(\alpha=0)$, then the house price $P_{0}$ reflects only these expected payments, as in Poterba (1984). But if rent is stochastic and households are risk-averse, the price also reflects the net risk premium, which is in the second term. The part of this term in brackets includes two premia for the two rent risks $\left(\mathrm{r}_{1}\right.$ and $\left.\mathrm{r}_{2}\right)$ avoided by owning the house, appropriately discounted, minus one premium for the risk due to the stochastic terminal house sale price $\mathrm{P}_{3}$. 
Because the rent shocks are IID, the house price risk is of the same magnitude as the rent risks, but comes further in the future and so is discounted more heavily. Therefore in this case the rent risks dominate, and the net risk premium is necessarily positive. That is, risk averse households will bid up the house price $\mathrm{P}_{0}$ relative to $\mathrm{r}_{0}$ because of the hedging benefit that the house provides against rent risk. In this case the price-rent differential would unambiguously rise with rent risk. ${ }^{14}$

If instead rent shocks are fully persistent, with $\rho=1$, then (2) implies that $\mathrm{P}_{0}-\mathrm{r}_{0}=(\mu /(1-\delta)$ $\left.+\mathrm{r}_{0}\right) \delta /(1-\delta)+1 / 2 \alpha \sigma_{\mathrm{r}}^{2}\left[\left\{\left(\delta+\delta^{2}\right)^{2}+\delta^{4}-3 \delta^{6} /(1-\delta)^{2}\right\} /\left(1-\delta^{3}\right)\right]$. In the third term in the square brackets, the house price risk is larger relative to the IID case, reflecting the fact that all three rent shocks are now fully persistent and so affect the house price. The net risk premium can therefore be negative, unlike the IID case. For example, for patient households the terminal price risk is now more likely to outweigh the earlier rent risks. ${ }^{15}$

In our MSA-level rent data $\rho$ is about 0.6-0.7. In this case, using a discount factor of $0.94,{ }^{16}$ the net risk premium is positive so long as the horizon $\mathrm{N}$ is greater than 3 to 4 years. However, in this stylized model the absolute level of the net premium is not as interesting as the fact that it increases with N. Generalizing equation (2) to an N-period horizon, the price-to-rent differential $\mathrm{P}_{0}-\mathrm{r}_{0}$ increases with $\mathrm{N}$. In a more realistic setting with households with different horizons, given the supply of housing, house prices would be determined by marginal households with a particular horizon. For households with a longer horizon than this, owning provides insurance against an even larger number of rent risks, for the same house price. Hence the hedging benefit of housing should still empirically rise with the household's horizon, even with endogenous house prices.

\footnotetext{
${ }^{14} \mathrm{We}$ assume a stationary equilibrium in which analogous conditions apply to the households buying the house in year 3. This is the source of the factor $1 /\left(1-\delta^{3}\right)$. Above we assumed that $P_{3}$ is determined when $r_{3}$ is observed at the start of period 3 in order to maintain this stationarity.

${ }^{15}$ Case and Shiller (1989) find that changes in house prices exhibit some persistence. That can be explained in our theoretical context if rents are not IID.

${ }^{16}$ This is consistent with a real mortgage rate of about $6 \%$.
} 
Another implication of the model is that the net risk premium also increases in $\alpha$, the household's risk aversion. Thus households that are more sensitive to risk, or equivalently households that take on larger housing gambles, should have a larger elasticity of homeownership demand to rent risk, ceteris paribus. Since this effect is multiplicative in equation (2), this elasticity will be largest for households with long horizons.

The manifestation of a greater hedging demand for home owning depends on the elasticity of supply of owner-occupied housing. If the supply is very elastic, an increase in demand for homeownership will result in a larger supply of units to be owned without much change in price. ${ }^{17}$ The homeownership rate will rise. On the other hand, if the supply of housing units to be owned is very inelastic, the increase in demand will be capitalized into higher house prices until households are again indifferent between owning and renting. In this case, house prices will rise without much change in the homeownership rate. In the intermediate case, the most likely outcome, there will be some effect on the homeownership rate and some effect on house prices. Accordingly, we will empirically estimate the effect of rent risk $\sigma_{r}^{2}$ on both the probability of owning and the price-rent differential.

Although the model presented in this section is stylized, its implications are quite general. Among the advantages and disadvantages of owning a home, one potentially important but previously neglected advantage is the hedge that it provides against rent risk. The model provides several empirical predictions. First, the net effect of rent variance $\sigma_{\mathrm{r}}^{2}$ on the demand for homeownership can be either positive or negative, depending on the relative size of the resulting cumulative rent risk and house price risk. Second, the demand for homeownership should increase with a household's expected horizon in its residence, N. Third, the demand for homeownership

\footnotetext{
${ }^{17}$ Since we hold the quantity of housing services demanded to be constant, the supply of owner-occupied houses in this context could be quite elastic even if land is inelastically supplied. In a market where a high rent variance induces more households to own, rental units can simply be converted into owner-occupied housing.
} 
should increase in the interaction of $\mathrm{N}$ and $\sigma_{\mathrm{r}}^{2}$. For households with a sufficiently long horizon, the demand should increase in $\sigma_{r}^{2}$, and for households with very short horizon, the demand for home owning may decrease in $\sigma_{r}^{2}$. Finally, the effect of rent risk on homeownership should be strongest for households with high risk aversion $\alpha$, and the demand for homeownership should increase in the interaction of $\alpha, \sigma_{r}^{2}$, and N. We empirically test these predictions in the remainder of this paper.

\section{Data and variable construction}

To estimate the model described in section I, we need rent and house price data at the market level and household level data on homeownership and demographic characteristics. To this end we combine four data sets.

We obtained an index of median apartment rents by MSA from Reis, a commercial real estate information company. ${ }^{18}$ The index runs annually from 1981 to 1998 , with 47 MSAs observed consistently throughout the sample. Rents are converted to real dollars using the CPI excluding shelter. For the empirical work, both rent growth and rent variance for a given year are computed over the preceding nine years. We calculate the rent variance $\left(\sigma_{r}^{2}\right)$ for each MSA as the de-trended variance in its rents over the prior nine years. The growth rate of rent is defined as the constant term from a regression of log rent on a constant over the same period. Rent variance is computed from the residuals of this growth regression, and thus is expressed as a percentage of the base rent. We use the log of rent to keep MSAs with high rent levels from appearing to have artificially high rent variances.

\footnotetext{
${ }^{18}$ Reis collects its data from surveys of owners of “Class A,” or top-quality, apartment buildings in each MSA.
} 
House price growth is computed in a similar manner for each MSA using the Freddie Mac repeat-sales house price index over the same time periods. To obtain the level of house prices in a given year, we inflate the MSA's median house price from the 1990 Census by the corresponding growth rate from the Freddie Mac index and convert to real dollars using the CPI excluding shelter. To estimate the effect of rent variance on house prices, we merge the rent and house price data sets by MSA, yielding 44 MSA-level observations per year. ${ }^{19}$ Due to the lags required, we can compute rent variance for only the 1990-1998 period, giving us a total of 396 MSA-year observations in the pooled data.

Table 1 presents summary statistics on MSA rents and prices. The volatility of rent is quite substantial. Between 1990 and 1998, the mean (across and within MSAs) standard deviation of real rent was 2.9 percent per year. This is over half of the size of the standard deviation of real house prices, which averaged 4.6 percent over the 1990 to 1998 period. The variability in rents dwarfed real rent growth- between 1990 and 1998 real rents grew only one-tenth of one percent on average per year. Real house price growth, as well, was approximately zero. Homeowners typically pay nearly 16 times the MSA's annual median apartment rent for their houses, though this figure varies considerably across MSAs. $^{20}$

Most of the sample means are fairly constant over time, exhibiting little difference between the 1990-1998 averages in the first panel of table 1 and the values for 1998 alone in the second panel. This implies that much of the variation in the data comes from the cross section of 44 MSAs rather than from changes over time. In particular, rent risk varies significantly across MSAs, with the standard deviation of the rent volatilities being 0.017 for $1990-98$ and 0.012 for 1998 . The

\footnotetext{
${ }^{19}$ Of the 47 MSAs with rent data, three do not have matching house price data.

${ }^{20}$ Part of the reason that owner-occupied housing commands such a large multiple to rent is that the median house price reflects a greater quantity of (or, equivalently, "nicer") housing than the median apartment rent does. As long as the difference between the amount of housing in the median house and in the median apartment does not spuriously vary across MSAs in a way that is correlated with rent variance, it will not affect our estimation.
} 
volatility of rent ranges from 1.4 percent standard deviation in Fort Lauderdale to 7.2 percent in Austin. In 1998 the rent risks were even larger relative to the house price risks, compared to earlier in the decade: the average standard deviation of real rent in 1998 was 2.3 percent and that of real house prices was 2.8 percent.

Homeownership rates and individual level data are obtained from the 1990 and 1999 Current Population Survey (CPS) March Annual Demographic Supplements. ${ }^{21}$ The CPS reports whether households own or rent their residences as well as a number of demographic variables such as age, race, education, occupation, number of children, marital status, and total household income. In addition, we impute the probability of a household's staying in the same residence (whether rented or owned) for another year as the proportion of households in that age-occupationmarital status cell (excluding the household in question) in that year that did not move in the previous year. $^{22}$

The sample averages of the key CPS variables are reported in table 2. In particular, in 1990 and 1999, 60 percent of the CPS households lived in an owner-occupied house. The cross sectional standard deviation in the probability of owning is 0.490 . This represents an enormous amount of variation, especially considering the fact that the national average homeownership rate has changed by only 3 percentage points in the last 20 years, from 65 to 68 percent. While 81 percent of households in Richmond own their house, only 33 percent of those in New York City and 53 percent of those in San Jose do.

The last two columns of table 2 report the means for the top and bottom halves of the variables' distribution. This division corresponds to how we will group the data in our empirical

\footnotetext{
${ }^{21} 1990$ is our earliest available year of data and 1999 is the most recent year when we maximize the amount of time between observations and the potential variation in rent variance. Since the rent variance for 1990 is computed over the 1981-1989 time period and the 1999 rent variance is computed over 1990-1998, there is no overlap in this rent variance sample when we combine 1990 and 1999.

${ }^{22}$ As is customary, we use the age and occupation of the household head.
} 
work. For example, on average 84 percent of the CPS households did not move in the last year. However, 25 percent $(=1-0.749)$ of the "movers" households - those below the median in the imputed probability of not moving - moved in the last year while only 6.4 percent $(=1-0.936)$ of

the "stayer" households - those above the median - moved. In the next row, the market-level rent data is matched to each CPS observation based on its MSA of residence. Households who live in "high" rent variance markets have a standard deviation of real rent of 4 percent, twice that of those in "low" rent variance markets.

\section{Empirical methodology and results}

This section empirically examines the hypothesis that the demand for home owning varies significantly with rent risk, as outlined in section I. If owner-occupied residences were perfectly elastically supplied, households who live in markets with higher rent variance would simply be more likely to be owners and the homeownership rate would be higher in those MSAs. On the other hand, if owner-occupied houses are at all inelastically supplied, at least some of the increase in demand for ownership will show up as a higher price of housing rather than a higher homeownership rate. This section presents four tests of this hypothesis, three concerning homeownership rates and one concerning house prices.

Starting with tenure choice, we will test whether "stayers," households who are less likely to move and so have a longer expected horizon in their residences, are more sensitive to rent variance than are "movers." If so, the difference in homeownership rates between stayers and movers should increase with rent variance. Similarly, we will examine whether the difference in the probability of homeownership between elderly households in high and low rent variance markets decreases as the households get older and thus the expected remaining time in the 
residence declines. Lastly, we investigate whether households which may be more sensitive to rent risk because local housing costs comprise a larger share of their budget are more likely to be homeowners in high rent risk markets than in low rent risk markets.

For house prices, we examine the effect of rent variance on the price-to-rent multiple at the MSA level. In markets where rent variance is greater or has increased we would expect to see a larger price-to-rent multiple, reflecting the additional value due to the rent hedging aspect of homeownership.

\section{III.1 The effect of rent risk on homeownership}

We begin by estimating probit models of the following form, on household level data from the 1990 and 1999 CPS:

$$
\begin{gathered}
O W N_{i, k, t}=\beta_{0}+\beta_{1} f\left(\sigma_{r}\right)_{k, t}+\beta_{2} g(P(S T A Y S))_{i, t}+\beta_{3} f\left(\sigma_{r}\right) \times g(P(S T A Y S))_{i, k, t} \\
+\theta X_{i}+\psi Z_{k, t}+\omega_{i}+\eta_{k, t}+\delta_{t}+\varepsilon_{i, k, t}
\end{gathered}
$$

where $i$ indexes the household, $k$ the MSA it lives in, and $t$ the year. OWN is an indicator variable that takes the value one if the household owns its house and zero otherwise. Consistent with the model in section I, equation (3) separately controls for both the volatility of rent and the household's expected horizon, as well as the interaction of these two variables. The standard deviation of rent in market $k$ is denoted by $\sigma_{\mathrm{r}, \mathrm{k}}$ and is computed over the 1980-1989 period for the 1990 observations and 1990-1998 for the 1999 observations. P(STAYS $)_{i, t}$ is the imputed probability that household $i$ does not move during year $t$, which corresponds to the horizon $N$ in section I. Since a homeowner with a large probability of staying would face the house price risk further in the future, and would avoid a greater number of rent risks, the probability of owning should rise with P(STAYS), ceteris paribus. As already noted, transactions costs of buying and 
selling a house will reinforce this effect. Thus $\beta_{2}$ should be positive. $X_{i}$ is a vector of household level controls from the CPS including log income and dummy variables for race, education, occupation, 10-year age categories, and marital status. ${ }^{23}$ MSA-level controls in the vector $Z_{k, t}$ include the average apartment rent and median house price in the preceding year, and the average real rent growth and house price growth rates over the preceding nine years. Unobserved household characteristics are denoted by $\omega_{\mathrm{i}}$ and unobserved MSA-level factors that might change over time by $\eta_{k, t}$. A dummy for 1999 is included to control for the unobserved year-specific factors $\delta_{\mathrm{t}}$. For robustness we will consider various functional-form transformations of the standard deviation of rent, denoted by $f(\cdot)$, and of the probability of staying, denoted by $g(\cdot)$. Since a number of variables, including the standard deviation of rent, vary only across markets within a given year, we correct the standard errors to account for the correlated shocks within MSA x year cells.

To begin, we estimate the average effect of rent risk on the probability of home owning by restricting $\beta_{3}$ to be zero and estimating $\beta_{1}$. The most straightforward method is to compare the probability of home owning for households in "high" rent variance locations versus that for households in "low" rent variance locations. Thus in the first panel of table $3, f\left(\sigma_{\mathrm{r}}\right)_{\mathrm{k}, \mathrm{t}}$ is an indicator variable that is equal to one when $\sigma_{\mathrm{r}, \mathrm{k}, \mathrm{t}}$ is greater than the median standard deviation of rents, which is about 0.027 .

Overall, the average household in a high rent variance MSA is only slightly more likely to be a homeowner than one that lives in a low rent variance MSA, by 2.8 percentage points. However this effect is not statistically significant (the standard error is 2.4 percentage points). Thus, the

\footnotetext{
${ }^{23}$ We can separately identify marital status, age, and occupation, even while controlling for the probability of staying, since the latter is imputed using the interaction of marital status, age, and occupation rather than the individual variables' levels.
} 
tradeoff between rent risk and house price risk appears to be a statistical wash for a household with the average expected length of stay in our sample, which is just over 6 years $(1 /(1-0.843))$.

Households with long expected lengths of stay are also more likely to be homeowners. In column 1, $g(\mathrm{P}(\mathrm{STAY}))$ equals one for households above the median imputed probability of staying and zero otherwise. The estimated coefficient implies that households with the longest horizons, or "stayers", are 3.6 percentage points more likely to own their homes than are "movers."

A more compelling test of the rent hedging benefit of home owning focuses on the interaction of rent risk and expected horizon, $f\left(\sigma_{\mathrm{r}}\right) * g(\mathrm{P}(\mathrm{STAY}))_{\mathrm{i}, \mathrm{k}, \mathrm{t}}$ in equation (3). According to the model of section I, the difference in the probability of home owning between longer and shorter expected horizon households should increase with the rent variance. Thus a significantly positive value for $\beta_{3}$ will confirm the importance of the rent hedging hypothesis. In addition, while unobserved MSA level characteristics could potentially bias the estimated coefficient $\beta_{1}$ on the standard deviation of rent, the estimated $\beta_{3}$ should still be consistent since it depends only on the interaction of household level characteristics with the MSA-level rent variance. Since we are in effect comparing the homeownership probabilities of high- and low-mobility households within an MSA, in order to affect our results any MSA-level unobservable characteristics would need to influence the homeownership decision for high- and low-mobility households differentially in each MSA, and that differential impact would have to vary across MSAs in a way that happened to be correlated with the rent variance. We believe this to be unlikely. Similarly, $\beta_{1}$ could be affected by unobserved household level characteristics that happen to be correlated with rent variance and the homeownership decision. However, as long as those characteristics do not systematically vary within mobility groups across MSAs, the interaction of mobility and rent variance will be cleanly identified. 
Column 2 of table 3 reports the results from estimating the full equation (3). The interaction term is set to one if the household lives in an MSA with a standard deviation of rent above the median and is above the median in expected length of stay in the house. The resulting estimate of $\beta_{3}$ is $0.042(0.014)$, and is statistically significant. Thus, relative to the difference between "movers" and "stayers" in low rent variance MSAs, "stayers" in high rent variance MSAs are 4.2 percentage points more likely to own their house than "movers" in the same places. Based on the estimate of $\beta_{1}$, the lower expected horizon households (who have an average imputed probability of staying of about 75 percent, or a horizon of about four years) are less than one percentage point more likely to own their houses if they live in a high rent variance location. These results support the hypothesis that the rent hedging aspect of home owning significantly increases the demand for homeownership so long as the homeowners' horizons are long enough for the rent risk to outweigh the house price risk.

Since the mobility/rent-risk interaction term is a combination household/MSA-level effect, we can control for all unobserved MSA characteristics and still identify $\beta_{3}$. For that purpose, in column 3 we include dummies for each MSA in each year at the expense of not identifying purely MSA-level characteristics, including the standard deviation of rent. Unlike the previous column which made use of the cross sectional variation in rent risk and homeownership rates between MSAs, this strategy uses only the variation from differences in homeownership between movers and stayers within MSAs. Although the estimated coefficient $\beta_{3}$ on the interaction term declines to 2.9 (1.1) percentage points, it remains significant. ${ }^{24}$

\footnotetext{
${ }^{24}$ These and subsequent conclusions persist when we include house price risk; i.e., the standard deviation of house prices computed analogously to rent risk. However, as section I highlights, house price risk is just an endogenous transformation of rent risk. Our analysis, motivated by equation (2), appropriately captures the net effect of both risks.
} 
The second panel of table 3 , columns 4 to 6 , imposes a different functional form restriction on the standard deviation of rent and the probability of staying. Instead of using an indicator variable for whether the values are above some threshold, we include each variable linearly. The interaction term is simply the product $\sigma_{\mathrm{r}} * \mathrm{P}(\mathrm{STAY})$. In the third row of column 5 , the estimated coefficient $\beta_{3}$ on this interaction term is 8.08 (2.77) and is statistically significant. The second-tolast row of table 3 translates the coefficient into an economically more meaningful number by multiplying it by the standard deviation of the interaction term, 0.011 (table 2). This value can be interpreted as a measure of the exposure to rent risk. The rent hedging benefit of home owning has a large effect on the homeownership rate: a one standard deviation increase in the interaction term, starting at its mean, would increase the probability of homeownership by 9.2 percentage points. Relative to a baseline value of 65 percent, this represents an economically significant effect. When we substitute MSA dummies for the MSA-level covariates, in column 6, the estimated coefficient $\beta_{3}$ declines slightly to 6.10 (1.77), but remains significant.

The estimated coefficients $\beta_{1}$ on the standard deviation of rent $\sigma_{\mathrm{r}}$ are consistent with the predictions of the model. In the first row of column $4, \beta_{1}$ is positive but insignificant, suggesting again that for the average household the probability of homeownership does not increase much with rent risk. In column $5, \beta_{1}$ is negative and significant at -6.29 (2.17), indicating that for the shortest horizon households, the asset price risk outweighs the rent risk. However, given the positive coefficient $\beta_{3}$ on the interaction term, if the expected horizon in the residence is greater than 4.5 years $(1 /(1-6.29 / 8.08))$, the rent risk dominates the asset price risk. This is the case for 
almost 75 percent of our sample. In sum, the results of this subsection indicate that rent risk significantly increases the demand for owner-occupied housing. ${ }^{25}$

\section{III.2 Rent risk and housing demand by the elderly}

The value of homeownership as a rent hedge may provide a partial explanation for why homeownership rates are so high among the elderly. If older or retired households are more risk averse, as is often assumed, they will value more highly the hedging benefit of owning and will be more likely to own. Counteracting that effect, however, is the fact that the closer a homeowner is to the end of her life, the less hedging value she receives from home owning. In other words, for the elderly the expected remaining lifespan is a reasonable proxy for the expected length of stay in the house $(\mathrm{N})$. Thus we would expect to find that older people should generally be more likely to own, but the probability of owning should decline as they approach the end of their lifetime.

While one could attribute a rising-then-falling life-cycle pattern of homeownership to the rent hedging benefit of owning, there are many other possible explanations. For example, low mobility among the elderly may explain their higher homeownership rates and declining health that requires nursing home care may cause them to be more likely to move out as they age further. However, the rent hedging hypothesis further predicts that homeownership rates among the elderly should be highest in high rent variance places since the value of the rent hedge would likely be the largest there. In addition, the decline in the probability of homeownership with age should be

\footnotetext{
${ }^{25}$ Davidoff (2001) points out that the covariance of income and house prices can affect households' portfolio allocations to housing. In our context the corresponding exogenous measure of risk would be the covariance of income and rent. In the presence of liquidity constraints, for example, a positive covariance might tilt a household towards renting. We have computed the covariance of household income with MSA level rent using industry, occupation, and wage data from repeated CPS cross sections and matched them to our 1999 sample. When we include them in the regressions in table 3 (although with only one year's worth of data), our results for the effect of rent risk are qualitatively the same and remain statistically significant. The estimated coefficients on the covariance terms are usually positive: a larger covariance of rent with income leads to increased homeownership. This effect is statistically significant, but only if we do not control for MSA fixed effects.
} 
steepest in high rent variance locations since the hedging benefit, which increases with the interaction term $\sigma_{r}^{2} \times \mathrm{N}$, is more sensitive there to the expected horizon. The life-cycle pattern of homeownership that is driven by other causes should not be affected by rent variance.

This difference in life-cycle patterns of homeownership can be seen in the unconditional homeownership rates by age. Using the pooled the 1990 and 1999 CPS cross-sections, we divided our 44 MSAs into high- and low-variance markets depending upon whether they were in the top quartile of rent variance or below the median, and used a kernel regression to compute the unconditional homeownership rate by age in each type of market. ${ }^{26}$ The result is presented in figure 1 . By age 40, homeownership rates are about 3 percentage points greater in high rent variance MSAs than in low rent variance MSAs. The difference grows with age and peaks for people in their early 60s, with 60-year-olds exhibiting homeownership rates of 76 percent in high rent variance places and 72 percent in low rent variance places. While the unconditional probability of homeownership declines with age starting in the late $60 \mathrm{~s}$, it falls fastest for people in high rent variance MSAs, consistent with the more rapid decline in the value of the rent hedge. By the time people are in their late 70s, with presumably short expected remaining lifetimes, the probabilities of homeownership in high- and low-rent variance MSAs have converged to approximately the same level.

While figure 1 presents unconditional homeownership rates by age, we would like to control for other observable factors that may vary systematically by age or with rent variance. We test these hypotheses with a more parametric specification by estimating the following spline equation using a probit model:

\footnotetext{
${ }^{26}$ Given the relatively small number of elderly in the data, this section emphasizes the top quartile of rent variance in order to make its points more starkly. The results are qualitatively similar using the top 50 percent.
} 


$$
\begin{gathered}
O W N_{i, k, t}=\gamma_{0}+\gamma_{1} A G E \times U N D E R 60_{i}+\gamma_{2} O V E R 60_{i}+\gamma_{3} A G E \times O V E R 60_{i}+\gamma_{4} f\left(\sigma_{r}\right)_{k, t}+ \\
\gamma_{5} A G E \times U N D E R 60 \times f\left(\sigma_{r}\right)_{i, k, t}+\gamma_{6} O V E R 60 \times f\left(\sigma_{r}\right)_{i, k, t}+\gamma_{7} A G E \times O V E R 60 \times f\left(\sigma_{r}\right)_{i, k, t}+ \\
\theta X_{i}+\psi Z_{k, t}+\omega_{i}+\eta_{k, t}+\delta_{t}+\varepsilon_{i, k, t}
\end{gathered}
$$

where AGE is the age in years of the head of household $i$, UNDER60 is an indicator variable that takes the value of one if the person is 60 years old or younger, OVER60 is an indicator variable that takes the value of one if the person is more than 60 years old. In some specifications, $f\left(\sigma_{\mathrm{r}}\right)_{\mathrm{k}, \mathrm{t}}$ is a dummy variable that equals one if MSA $k$ in year $t$ is in the top quartile of rent variance (high) or zero for the bottom three quartiles (low). Alternatively, it is the standard deviation of rent entered linearly. The terms that are not interacted with $f\left(\sigma_{\mathrm{r}}\right)_{\mathrm{k}, \mathrm{t}}\left(\right.$ i.e., $\gamma_{0}$ to $\left.\gamma_{3}\right)$ correspond to the dashed line in figure 1 (low rent variance). The terms that are interacted $\left(\gamma_{4}\right.$ to $\left.\gamma_{7}\right)$ measure the differences in level and slope between the solid line in figure 1 (high rent variance) and the dashed line. The hypothesis that older households are in general more risk averse concerning rent variance implies that $\gamma_{6}$ should be positive. But if the age-ownership profile is more steeply declining in high variance places, $\gamma_{7}$ should be negative. Once again, the specification includes detailed household controls for income, year, race, education, occupation, expected mobility, and marital status, as well as MSA x year dummies.

The most direct test of the model focuses just on the elderly and thus the first column of table 4 uses only those households where the respondent is over the age of 60 . By including MSA $\mathrm{x}$ year effects, we are comparing the slopes of the post-60 homeownership age profile in high and low rent variance places but are controlling for differing levels of homeownership. The results bear out the predictions of the rent hedging hypothesis. Most notably, $\gamma_{7}$ is significantly negative, implying that homeownership declines more rapidly with age in high rent variance places. Relative to people over 60 in low rent variance places, the probability of homeownership for people over 60 in high rent variance MSAs falls by $0.29(0.14)$ percentage points more per year of age. This is a 
considerable difference because, controlling for other covariates, the probability of homeownership for people over 60 in low rent variance places is nearly constant over their remaining lifetimes.

In column 2, we include in the sample households of all ages and constrain the coefficients on the covariates to be the same for the entire sample. Again, by including fixed effects to control for unobserved MSA x year differences, we also absorb cross sectional and across time differences in the average homeownership rate and use the curvature of the age profile within MSA/year cells to identify our effect. As a baseline, based on $\gamma_{1}$, households aged 60 or below with rent variance in the bottom three quartiles have a probability of homeownership that increases at a rate of 1.4 percentage points per year. In top-quartile rent variance MSAs, the probability of homeownership rises 0.16 percentage points $(0.07)$ faster per year, until at age 60 households are 10.4 (3.3) percentage points more likely to be homeowners than people of the same age in low rent variance places. Thus homeownership among older households rises with rent variance. We find virtually the same relative effect for over- 60 households as we did before: the probability of homeownership declines more rapidly for households in high rent variance areas, since $\gamma_{7}$ is significantly negative. ${ }^{27}$

These results are generally robust to specification changes. The second panel in table 4 parameterizes rent variance with a continuous linear function. We obtain similar qualitative effects as in the first panel, although the interaction of rent variance with age-over-60 is no longer statistically significant. We have also estimated a quadratic age profile of homeownership, and allowed this profile to be different in high- and low-variance places. Again, older people in high variance places have a higher overall probability of homeownership but a steeper decline with age,

\footnotetext{
${ }^{27}$ The only notable difference between columns (1) and (2) is that in column (2) households over age 60 in low rent variance places have homeownership rates that increase with age. This result is an artifact of not allowing an MSA/year-specific over-60 intercept, as we did in column (1), and constraining the effects of the covariates to be the same for young and old households. This is why we place our emphasis on the difference in slopes between high and low rent variance places, which is better identified than the slopes themselves.
} 
with the differences being statistically significant. We have also replaced the "over 60 " indicator with an indicator variable for the household's head being retired, with similar qualitative results.

\section{III.3 Rent risk and budget shares for housing}

Households for whom housing is a larger portion of their budgets or wealth might be more sensitive to rent risk since they are effectively taking a larger gamble. We test this hypothesis by dividing the sample based on the ratio of the average rent in the MSA to actual household income. We use MSA-level rent instead of the household's own rent since the former is exogenous to the household and is defined even for homeowners. Households that live in markets where rents are high relative to their own incomes would generally need to spend more of their budget on housing to obtain the same housing service flow relative to someone who lives in a low rent market. The direct effect of the rent-to-income ratio on the probability of homeownership is uncertain since it depends on whether rent risk or house price risk dominates for the average household. However, one might expect to find that as expected horizon increases, households with higher rent-to-income ratios might be increasingly more likely to own than other households. Finally, homeownership rates would be highest among those with high rent-to-income ratios, long expected lengths of stay, and high rent risk. As before, we estimate a probit model on household level data from the 1990 and 1999 CPS:

$$
\begin{aligned}
\text { OWN }_{i, k, t}= & \rho_{0}+\rho_{1} f\left(\sigma_{r}\right)_{k, t}+\rho_{2} h(R / Y)_{i, k, t}+\rho_{3} f\left(\sigma_{r}\right) \times h(R / Y)_{i, k, t}+\rho_{4} g(P(\text { STAYS }))_{i, t} \\
& +\rho_{5} g(P(\text { STAYS })) \times h(R / Y)_{i, k, t}+\rho_{6} f\left(\sigma_{r}\right) \times g(P(\text { STAYS }))_{i, k, t} \\
+ & \rho_{7} f\left(\sigma_{r}\right) \times g(P(S T A Y S)) \times h(R / Y)_{i, k, t}+\theta X_{i}+\psi Z_{k, t}+\omega_{i}+\eta_{k, t}+\delta_{t}+\varepsilon_{i, k, t}
\end{aligned}
$$

where $R / Y$ is the rent-to-income ratio. The other variables and household level controls are defined as in the previous subsections. As before, we will estimate two specifications. First, we estimate a discretized version where high rent variance and "stayer" households are each above the median 
and high rent-to-income households are in the top quartile. ${ }^{28}$ Second, we let each of the variables enter linearly. For these regressions we symmetrically trim the top and bottom one percent of the rent-to-income distribution since households with zero or very low values for income appear to have very high rent-to-income ratios and so could potentially skew the results. This sampling reduces our number of observations to 39,468 from 40,274 households. ${ }^{29}$ All regressions include the usual household controls, and MSA x year dummies which again subsume the uninteracted rent variance terms.

The results are reported in table 5. In the first column, we estimate the differential effect of rent variance and length of stay on high and low rent-to-income households. The results are consistent with the budget-share hypothesis. First, according to the estimate for $\rho_{5}$, stayers who are in the high rent-to-income group are 4.4 percentage points more likely to be homeowners than movers in that group, relative to the difference in probability of homeownership between movers and stayers with low rent-to-income ratios. Second, $\rho_{6}$ implies the same result as in table 3 : households with longer expected lengths of stay are more sensitive to rent risk. Stayers in high rent variance areas are 3.2 percentage points more likely to be homeowners than are movers, relative to stayers and movers in low rent variance areas. Both of these estimated effects are statistically significant. Also, households who live in markets where rent-to-income ratios are in the top quartile are 3.5 percentage points less likely to own their homes than households with low ratios.

In the second column of table 5, we test the triple-interaction effect $\left(\mathrm{N} \mathrm{x} \sigma_{\mathrm{r}} \times \mathrm{R} / \mathrm{Y}\right)$ : Are the highest homeownership rates exhibited by households in high rent variance MSAs, with long

\footnotetext{
${ }^{28}$ This cutoff roughly corresponds to households for whom average rents equal a third of their annual incomes. That is the budget allocation to housing typically recommended by financial planners.

${ }^{29}$ Predictably, this sampling has virtually no effect on any of the estimated coefficients in the discretized specification in columns 1 and 2. It also has little effect on the triple-interaction term in columns 4 and 6 , but reduces the magnitude of the rent-to-income level and single-interaction terms.
} 
expected lengths of stay, and with high rent-to-income ratios? Indeed, that is what we find. Such households are 5.4 percentage points more likely to be homeowners, a statistically significant effect. This triple-interaction specification controls for unobserved differences between movers and stayers, high rent variance MSAs and low variance ones, and high rent-to-income and low rent-toincome households. It even allows for unobserved differences within the main sets of interactions: moving/staying and rent variance, rent variance and rent-to-income, and moving/staying and rentto-income. The MSA x year effects control for unobserved MSA level characteristics that change over time.

In columns 3 through 6 , we use different functional forms of the key variables to demonstrate the robustness of the results. In columns 3 and 4, we continue to use an indicator variable for high and low rent-to-income households but let the standard deviation of rent and the probability of staying enter linearly. Since rent/income can be quite high for households with very low income, using a dummy for $\mathrm{R} / \mathrm{Y}$ reduces the impact of the measurement error. In column 3, the significant results are that homeownership increases with expected horizon $(\mathrm{N})$, as does the sensitivity to rent risk $\left(\mathrm{N}^{*} \sigma_{\mathrm{r}}\right)$. These results are consistent with those in table 3 . In column 4 , we still find that rent risk increases the likelihood of homeownership most for households who expect to be in their houses longer $\left(\mathrm{N}^{*} \sigma_{\mathrm{r}}\right)$, but the effect is increasingly pronounced as the rent-to-income ratio increases. In the last row, the estimated coefficient on the triple-interaction term is 9.433 (4.381). ${ }^{30}$ Columns 5 and 6 , which also enter rent-to-income linearly, produce qualitatively similar results, though the statistical significance of the triple interaction term in column 6 is diminished.

\section{III.4 The effect of rent risk on house prices}

\footnotetext{
${ }^{30}$ The negative and significant coefficient on $\sigma_{\mathrm{r}} \mathrm{x} R / \mathrm{Y}$ interaction term suggests again that price risk dominates for households with short horizons.
} 
In the previous subsections, we found evidence that some of the hedging demand for homeownership was met by increasing the supply of owner-occupied housing and thus increasing the homeownership rate. In this subsection we look for effects of the hedging demand on house prices. We estimate the following equation in MSA level data using OLS:

$$
\frac{P}{R}_{k, t}=\kappa_{0}+\kappa_{1} \sigma_{r, k, t}+\psi Z_{k, t}+\delta_{t}+\mu_{k, t},
$$

where $(P / R)_{k, t}$ is the price-to-rent multiple in MSA $k$ in year $t, \sigma_{\mathrm{r}, \mathrm{k}, \mathrm{t}}$ is the standard deviation of rent, and $Z_{k, t}$ is a vector of observable MSA characteristics, including the growth rate of real rent. Just as a price-earnings multiple for stocks should be higher for firms with higher expected future earnings growth, $\mathrm{P} / \mathrm{R}$ should be higher for MSAs with higher expected future rent growth. Since $\mathrm{R}_{\mathrm{k}, \mathrm{t}}$ controls for the overall demand for living space, the rent hedging value of ownership should show up as a larger price-to-rent multiple (assuming the supply of owner-occupied housing is not fully elastic). That is, using the ratio of prices to rents controls for shocks to the overall housing market, which impact both owner-occupied housing and rental housing. Controlling for the growth rate of rent, the price-rent multiple will then capture the net risk premium associated with rent risk, as in section I. Differences over time that are common to all MSAs are controlled for using year dummies, $\delta_{t}$.

We estimate this model on a panel of 44 MSAs observed over the 1990-1998 time period. For each year $t=1990-1998$, we calculate real rent variance and growth over the prior (rolling) nineyear period. For example, for $1990, \sigma_{\mathrm{r}, \mathrm{k}}$ and rent growth (in $Z_{\mathrm{k}, \mathrm{t}}$ ) are calculated over 1981-1989, and for 1998 they are calculated over 1990-1997.

Table 6 reports the results. We find consistent evidence that the rent hedging benefit of owner-occupied housing is capitalized into larger price-to-rent multiples. The first column of table 6 presents the results from the pooled cross section, without controls for MSA fixed effects. MSAs 
with a greater standard deviation of rent have a significantly greater price-to-rent multiple, with the estimated coefficient $\kappa_{1}$ being 34.5 (11.9). The last row of table 6 helps to gauge the economic significance of this result. A one standard deviation increase in $\sigma_{\mathrm{r}, \mathrm{k}, \mathrm{t}}$ (i.e., of about 0.018 ) is estimated to increase the price-to-rent ratio by 0.62 . Since the mean price-to-rent ratio is 15.7 , this amounts to a 3.9 percent rise in house prices, holding rents constant, which is a sizable effect. Further, real rent growth is capitalized into the price-to-rent multiple, as expected, with an estimated coefficient of 69.0. Thus, house prices appear to incorporate both expected future rents and the associated risk premia, consistent with the model underlying equation (2), and more generally with asset-pricing models of other, financial assets.

We next incorporate MSA fixed effects to control for MSA level observable and unobservable characteristics that do not change over time. Since the specification also includes year dummies, we are using the within-MSA relative variation in rent variance, rent growth, and the price-to-rent ratio over time to identify the rent hedging effect. (Recall that the rent variance $\sigma_{\mathrm{r}, \mathrm{k}, \mathrm{t}}$ and rent growth $\mathrm{k}_{\mathrm{k}, \mathrm{t}}$ within an MSA changes over time as the rolling window over which we compute them moves.) However, the MSA dummies remove a potentially powerful source of variation in rent variance, differences across MSAs. ${ }^{31}$

Even controlling for MSA and year fixed effects, in column 2 we find that when rent variance in a given MSA is higher, the price-to-rent ratio is higher. The estimated coefficient $\kappa_{1}$ on the standard deviation of rent, 11.0 (5.6), implies that a one standard deviation increase in $\sigma_{\mathrm{r}, \mathrm{k}, \mathrm{t}}$ leads to a 0.20 increase in the price-to-rent multiple. Although smaller than in the previous column, it still implies a 1.3 percent increase in house prices (from the base $\mathrm{P} / \mathrm{R}$ multiple of 15.7 )

\footnotetext{
${ }^{31}$ Note that one would not find much by looking at changes in the probability of home owning within MSAs over time since homeownership and housing construction are slow to respond to changes in rent variance. However, since prices adjust more readily, changes in expected rent variance should be more quickly incorporated into prices and thus be more easily detectable in the data on price-to-rent ratios.
} 
for a given rent level, and is statistically significant. The smaller magnitude is not surprising considering that only within MSA variation is being used for identification. Rent growth also continues to have the expected positive effect, with an estimated coefficient of 16.7 (4.7). In column 3, we account for MSA level heterogeneity by estimating equation (4) in first differences. This specification emphasizes the additional information that arrives over time, since the difference in the computed rent variance between one year and the previous year is due to adding the most recent year of data and discarding the oldest year. The results are almost identical to those in column 2 , although more precisely measured, with the estimated coefficient $\kappa_{1}$ being 10.1 (3.8).

Overall, the results consistently show that the rent hedging benefits of home owning are partly capitalized into house prices, in addition to increasing the probability of home owning.

\section{Conclusion}

One frequently overlooked but potentially important benefit to homeownership is the hedge that it provides against the risk of fluctuations in future rent payments. Home owning provides a predictable way of paying for housing services. With renting, the future cost of obtaining housing services is uncertain. On the other hand, homeowners face asset price risk while renters do not. Thus while homeownership provides a hedge against rent risk, its value is tempered by the associated asset price risk.

We presented a simple model of tenure choice in the presence of both rent risk and house price risk. The demand for homeownership increases with rent variance, given house price risk. Even with endogenous house prices, such that house price risk increases with the rent risk, demand still increases with rent risk for people who expect to stay in their residences for a sufficiently long time. These people avoid a greater number of rent risks by owning, and their future asset price risk 
is more heavily discounted. Thus the model implies that the hedging demand for homeownership increases with households' expected horizon in their residence, and with the interaction of horizon with rent risk. To the degree that the resulting hedging demand is capitalized into house prices, the price-to-rent multiple should be higher in places with higher rent variance and, to the degree that the supply of owned housing is elastic, the probability of home owning should rise with the variance of rent.

We used these results to motivate an empirical investigation into the effect of rent risk on the probability of home owning and on house prices. We controlled for MSA-level heterogeneity and other factors by comparing households that should be differentially affected by rent variance only because of different expected horizons in their residences. This isolated the effect of rent risk from other factors that influence homeownership. Notably, the effect of rent risk was found to be significantly greater for households with longer horizons. A one standard deviation increase in the exposure to rent variance (expected horizon interacted with the standard deviation of rent) would lead to a 7 to 9 percentage point increase in the homeownership rate. Also consistent with the model, older households are particularly sensitive to rent risk, with people aged 60 residing in MSAs with a top-quartile rent variance being over 10 percentage points more likely to be homeowners than people of the same age in low rent variance MSAs (conditional on household demographic characteristics and MSA fixed effects). Confirming that this effect is due to rent risk, the probability of homeownership drops most rapidly with age for elderly who live in high rent variance places, consistent with the rent hedging benefit declining with their expected lengths of stay. Also, households for whom market rents are high relative to their incomes respond the most to rent risk, especially if their expected horizon is large. 
We also found evidence that some of the hedging demand of home owning shows up in the multiple of rents people are willing to pay for houses. Even controlling for MSA-level fixed effects, we found that when MSAs have higher rent variance their house prices increase relative to the rental value of the housing stock. That is, house prices reflect not only expected future rents, but also the associated rent-risk premia, consistent with asset-pricing models of financial assets.

These results have a number of implications for housing markets and other decisions for which housing wealth is important. The rent hedging benefit of homeownership appears to be a significant factor in the demand for homeownership. For comparison, a typical cross-sectional estimate of the user cost elasticity of home owning implies that a one standard deviation increase in user cost would lead to about a 2.5 percentage point rise in the homeownership rate. The estimated effect in table 3 of a one standard deviation increase in the effective rent variance is about three times larger.

Another way to gauge the economic significance of the results is to calculate how much rent risk contributes to homeownership rates and house prices overall. Using our estimates from the fifth column of table 3 , we computed the difference between the predicted probability of homeownership and the predicted probability assuming rent variance was equal to zero. For nearly 75 percent of our sample households, the likelihood of homeownership would increase, on average by 3.3 percent. For some households, the probability of homeownership would increase by as much as 10 percent if rent risk were eliminated. The effect of rent risk on house prices, computed from our estimates in table 6, also is large. Using the smaller estimates from the second column, if there were no rent risk then house prices relative to rents would decline by 2.3 percent on average and by as much as 7 percent in some MSAs. 
For older households, the rent insurance aspect of home owning may help explain why the elderly do not usually become renters and why, when they do, they usually do so very late in life. Because they value highly the hedge against rent risk, it is more costly for them to become renters than previous analyses have assumed. This effect also implies that one should not simply assume that all housing wealth of the elderly is available for consumption. In the absence of viable reverse mortgage markets that let the elderly consume their housing wealth, the insurance benefit of home owning may keep many elderly from selling their homes. ${ }^{32}$

\footnotetext{
${ }^{32}$ We presume that the transactions costs involved in moving to a smaller owned unit would further discourage such sales.
} 


\section{References:}

Berkovec, James and Don Fullerton. "A General Equilibrium Model of Housing, Taxes, and Portfolio Choice.” Journal of Political Economy, vol. 100 (2), April 1992, pp. 390-429.

Brueckner, Jan. "Consumption and Investment Motives and the Portfolio Choices of Homeowners." Journal of Real Estate Finance and Economics, vol. 15, September 1997, pp. 159-180.

Campbell, John, and Joao Cocco. "Household Risk Management and Optimal Mortgage Choice." Mimeo, Harvard University, January 2002.

Caplin, Andrew. "The Reverse Mortgage Market: Problems and Prospects." Innovations in Housing Finance for the Elderly, Olivia Mitchell, ed. Pension Research Council (2001).

Case, Karl, and Robert Shiller. "The Efficiency of the Market for Single-Family Homes." American Economic Review, vol. 79 (1), March 1989, pp. 125-137.

Chan, Sewin. “Spatial Lock-In: Do Falling House Prices Constrain Residential Mobility?” Journal of Urban Economics, vol. 49 (3), May 2001, pp. 567-586.

Cocco, Joao. "Hedging House Price Risk with Incomplete Markets." Mimeo, London Business School, September 2000.

Davidoff, Thomas. "Labor Income, Housing Prices, and Homeownership." Mimeo, Massachusetts Institute of Technology, November 2001.

Engelhardt, Gary. "Consumption, Down Payments, and Liquidity Constraints." Journal of Money, Credit, and Banking, 28:2 (May) 1996: 255-271.

Flavin, Marjorie and Takashi Yamashita. "Owner-Occupied Housing and the Composition of the Household Portfolio Over the Life Cycle." American Economic Review, forthcoming.

Fratantoni, Michael. "Housing Wealth, Precautionary Saving, and the Equity Premium." Mimeo, Fannie Mae, July 1997.

Genesove, David. “The Nominal Rigidity of Apartment Rents.” NBER Working Paper \#7137, May 1999.

Genesove, David, and Christopher Mayer. "Equity and Time to Sale in the Real Estate Market." American Economic Review, vol. 87 (3), June 1997, pp. 255-269.

Goetzmann, William. "The Single Family Home in the Investment Portfolio." Journal of Real Estate Finance and Economics, Vol. 6 (3) p. 201-22. May 1993. 
Haurin, Donald. "Income Variability, Homeownership, and Housing Demand." Journal of Housing Economics, March 1991, 1 (1), 60-74.

Hendershott, Patric and Joel Slemrod. "Taxes and the User Cost of Capital for Owner-Occupied Housing." AREUEA Journal, Winter 1983, 10 (4), 375-393.

Henderson, J.V. and Ioannides, Y.M. "A Model of Housing Tenure Choice." American Economic Review, Vol. 73 (1), p. 98-113, March 1983.

Megbolugbe, Sa-Aadu, and James Shilling. "Oh, Yes, the Elderly Will Reduce Housing Equity under the Right Circumstances." Journal of Housing Research, vol. 8 (1) p.53-74, 1997.

Poterba, James. "Tax Subsidies to Owner-Occupied Housing: An Asset Market Approach.” Quarterly Journal of Economics, November 1984, 99 (4), 729-752.

Poterba, James and Andrew Samwick. "Household Portfolio Allocation Over the Life Cycle," NBER Working Paper \#6185, September 1997.

Rosen, Harvey. "Housing Decisions and the U.S. Income Tax." Journal of Public Economics, February 1979, 11 (1), 1-23.

Rosen, Harvey, Kenneth Rosen, and Douglas Holtz-Eakin. "Housing Tenure, Uncertainty, and Taxation." Review of Economics and Statistics, vol. 66, no. 3 (August 1984), pp.405-416.

Skinner, Jonathan. "Housing and Saving in the United States," in Noguchi and Poterba, eds, Housing Markets in the United States and Japan, NBER, University of Chicago Press, 1994 (pp191-213)

Skinner, Jonathan. "Housing Wealth and Aggregate Saving," Regional Science and Urban Economics, Vol. 19 (2), p.305-24, May 1989.

Skinner, Jonathan. "Is Housing Wealth a Sideshow?" in David Wise, ed, Advances in the Economics of Aging, NBER, University of Chicago Press, 1996 (pp241-68)

Stein, Jeremy. "Prices and Trading Volume in the Housing Market: A Model with Downpayment Constraints." Quarterly Journal of Economics, vol. 110 (2), May 1995, pp.379-406.

Summers, Lawrence. "Inflation, the Stock Market, and Owner-Occupied Housing." American Economic Review, vol. 71 (2), May 1981, pp. 429-434.

Venti, Steven and David Wise. “Aging and Housing Equity.” NBER Working Paper \#7882, September 2000.

Venti, Steven and David Wise. "Aging and the Income Value of Housing Wealth." Journal of Public Economics. Vol 44 (3) p.371-97, April 1991 
Venti, Steven and David Wise. “Aging, Moving, and Housing Wealth.” In David Wise, ed., The Economics of Aging. Chicago: University of Chicago Press, 1989.

Venti, Steven and David Wise. "But They Don't Want to Reduce Housing Equity." In David Wise, ed., Issues in the Economics of Aging, Chicago: University of Chicago Press, 1990. 
Table 1: Summary statistics for MSA-level data

\begin{tabular}{lcccc}
\hline \multicolumn{1}{c}{ Variable } & \multicolumn{2}{c}{$\mathbf{1 9 9 0 - 1 9 9 8}$} & \multicolumn{2}{c}{ 1998 only } \\
\cline { 2 - 5 } & Mean & Std. Dev. & Mean & Std. Dev. \\
\hline $\begin{array}{l}\text { Standard deviation } \\
\text { of real rent }\end{array}$ & 0.029 & 0.017 & 0.023 & 0.012 \\
$\begin{array}{l}\text { Standard deviation of real } \\
\text { house price }\end{array}$ & 0.046 & 0.031 & 0.028 & 0.016 \\
Real rent growth & 0.001 & 0.019 & 0.002 & 0.013 \\
Real house price growth & 0.006 & 0.031 & -0.001 & 0.021 \\
$\begin{array}{l}\text { Average real rent } \\
\text { Median real house } \\
\text { price }\end{array}$ & 6,331 & 1,505 & 6,748 & 1,607 \\
Price-to-rent ratio & 102,773 & 49,841 & 107,527 & 48,415 \\
Number of observations & 15.72 & 4.08 & 15.52 & 3.57 \\
\hline \hline
\end{tabular}

Notes: The first panel reports the average for all MSAs over the 1990-1998 time period. The second panel reports the average across the 44 MSAs in 1998 only. The standard deviations of rent and house prices, rent growth, and house price growth are all computed over the preceding nine years. The rent data are obtained from Reis. House price growth is computed from the Freddie Mac repeat sales house price index. To compute the level of house prices, the MSA median house price from the 1990 Census is inflated to the current year using the Freddie Mac index. All dollar values are in real (1990) dollars, deflated by the CPI less shelter. 


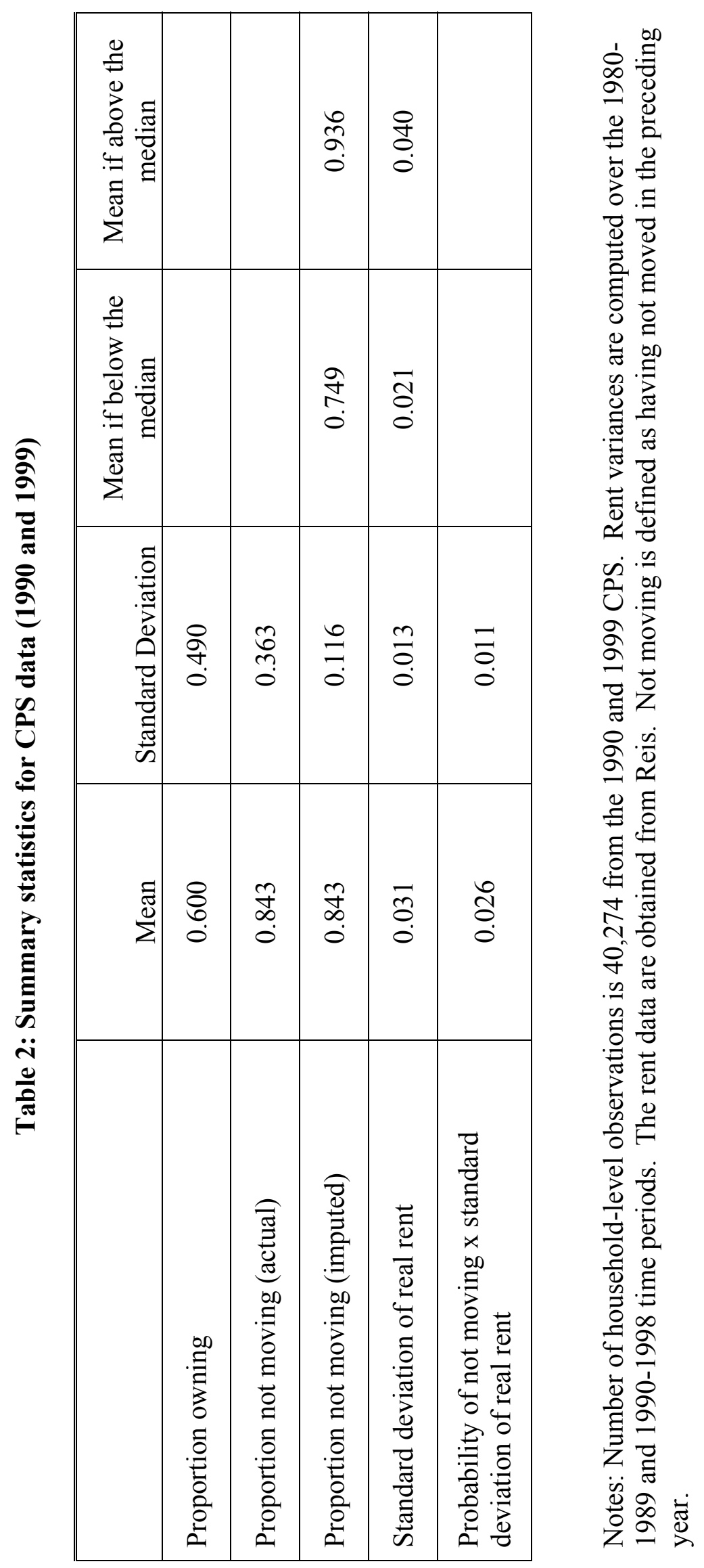


Table 3: The effect of rent risk on the probability of homeownership

\begin{tabular}{|c|c|c|c|c|c|c|}
\hline \multirow[b]{3}{*}{$\begin{array}{l}\text { Standard deviation of } \\
\text { real rent }\left(\sigma_{\mathrm{r}}\right)\left[\beta_{1}\right]\end{array}$} & (1) & (2) & (3) & (4) & $(5)$ & (6) \\
\hline & \multicolumn{3}{|c|}{$\begin{array}{c}\text { Indicator variables for } \\
\text { high rent variance and } \\
\text { high probability of staying }\end{array}$} & \multicolumn{3}{|c|}{ Continuous variables } \\
\hline & $\begin{array}{c}0.028 \\
(0.024)\end{array}$ & $\begin{array}{c}0.008 \\
(0.022)\end{array}$ & & $\begin{array}{c}0.339 \\
(0.686)\end{array}$ & $\begin{array}{l}-6.285 \\
(2.174)\end{array}$ & \\
\hline $\begin{array}{l}\text { Probability of staying } \\
\text { (N) }\left[\beta_{2}\right]\end{array}$ & $\begin{array}{c}0.036 \\
(0.011)\end{array}$ & $\begin{array}{c}0.015 \\
(0.013)\end{array}$ & $\begin{array}{c}0.020 \\
(0.011)\end{array}$ & $\begin{array}{c}0.652 \\
(0.070)\end{array}$ & $\begin{array}{c}0.395 \\
(0.095)\end{array}$ & $\begin{array}{c}0.448 \\
(0.081)\end{array}$ \\
\hline $\begin{array}{l}\operatorname{Pr}(\text { Staying }) \times \text { s.d. of } \\
\text { real rent }\left(\mathrm{N} \times \sigma_{\mathrm{r}}\right)\left[\beta_{3}\right]\end{array}$ & & $\begin{array}{c}0.042 \\
(0.014)\end{array}$ & $\begin{array}{c}0.029 \\
(0.011)\end{array}$ & & $\begin{array}{c}8.081 \\
(2.771)\end{array}$ & $\begin{array}{c}6.100 \\
(1.772)\end{array}$ \\
\hline MSA controls & Yes & Yes & No & Yes & Yes & No \\
\hline MSA x year dummies & No & No & Yes & No & No & Yes \\
\hline Household controls & Yes & Yes & Yes & Yes & Yes & Yes \\
\hline Pseudo R-squared & 0.2352 & 0.2355 & 0.2498 & 0.2371 & 0.2375 & 0.2520 \\
\hline $\begin{array}{l}\text { A one standard } \\
\text { deviation in staying } \mathrm{x} \\
\sigma_{\mathrm{r}} \text { leads to... }\end{array}$ & & & & & $\begin{array}{c}0.092 \\
(0.032)\end{array}$ & $\begin{array}{c}0.069 \\
(0.020)\end{array}$ \\
\hline
\end{tabular}

Notes: Estimated coefficients are marginal effects from probit regressions of equation (3) estimated on 40,274 households in 44 MSAs in 1990 and 1999. The dependent variable takes the value of one if the household is a homeowner. All specifications include year dummies. MSA controls include median real rent, median real house price, real rent growth, and real house price growth. Household controls include log household income and dummies for the head's occupation, age, race, education, and marital status. MSAs are deemed to have high rent variance if $\sigma_{\mathrm{r}}$ is above the median household's value of 2.8 percent. The probability of staying is high if the household is above the median probability of 88 percent. All dollar values are in real (1990) dollars, deflated by the CPI less shelter. For specifications that do not include MSA x year dummies, the standard errors, in parentheses, are adjusted for correlation within MSA/year. 
Table 4: Rent risk and homeownership by the elderly

\begin{tabular}{|c|c|c|c|c|}
\hline & $(1)$ & $(2)$ & (3) & (4) \\
\hline & \multicolumn{2}{|c|}{$\begin{array}{l}\text { Indicator variable for } \\
\text { high rent variance }\end{array}$} & \multicolumn{2}{|c|}{ Continuous rent variance } \\
\hline Age if 60 or below $\left[\gamma_{1}\right]$ & & $\begin{array}{c}0.0141 \\
(0.0005)\end{array}$ & & $\begin{array}{c}0.0086 \\
(0.0009)\end{array}$ \\
\hline Age if 60 or below $\times \sigma_{\mathrm{r}}\left[\gamma_{5}\right]$ & & $\begin{array}{c}0.0016 \\
(0.0007)\end{array}$ & & $\begin{array}{c}0.056 \\
(0.025)\end{array}$ \\
\hline Age $>60$ dummy $\left[\gamma_{2}\right]$ & & $\begin{array}{c}0.557 \\
(0.010)\end{array}$ & & $\begin{array}{c}0.414 \\
(0.029)\end{array}$ \\
\hline Age $>60$ dummy $\times \sigma_{\mathrm{r}}\left[\gamma_{6}\right]$ & & $\begin{array}{c}0.104 \\
(0.033)\end{array}$ & & $\begin{array}{c}3.598 \\
(1.303)\end{array}$ \\
\hline Age if over $60\left[\gamma_{3}\right]$ & $\begin{array}{l}-0.0006 \\
(0.0007)\end{array}$ & $\begin{array}{c}0.0019 \\
(0.0009)\end{array}$ & $\begin{array}{l}-0.0006 \\
(0.0016)\end{array}$ & $\begin{array}{c}0.002 \\
(0.002)\end{array}$ \\
\hline Age if over $60 \times \sigma_{\mathrm{r}}\left[\gamma_{7}\right]$ & $\begin{array}{l}-0.0029 \\
(0.0014)\end{array}$ & $\begin{array}{l}-0.0035 \\
(0.0017)\end{array}$ & $\begin{array}{l}-0.0559 \\
(0.0495)\end{array}$ & $\begin{array}{l}-0.066 \\
(0.059)\end{array}$ \\
\hline MSA x year dummies: & Yes & Yes & Yes & Yes \\
\hline Household controls: & Yes & Yes & Yes & Yes \\
\hline Sample: & Age $>60$ & All & Age $>60$ & All \\
\hline Number of observations: & 9,699 & 40,274 & 9,699 & 40,274 \\
\hline R-squared & 0.1989 & 0.2526 & 0.1992 & 0.2550 \\
\hline
\end{tabular}

Notes: Estimated coefficients are marginal effects from probit regressions estimated on 40,274 households in 44 MSAs in 1990 and 1999. The coefficients in brackets correspond to equation (4). The dependent variable takes the value of one if the household is a homeowner. All specifications include MSA x year dummies. Household controls include log household income, probability of not moving, and dummies for the head's occupation, race, education, and marital status. MSAs are deemed to have high rent variance if $\sigma_{\mathrm{r}}$ is above the $75^{\text {th }}$ percentile household's value of 4.1 percent. All dollar values are in real (1990) dollars, deflated by the CPI less shelter. 


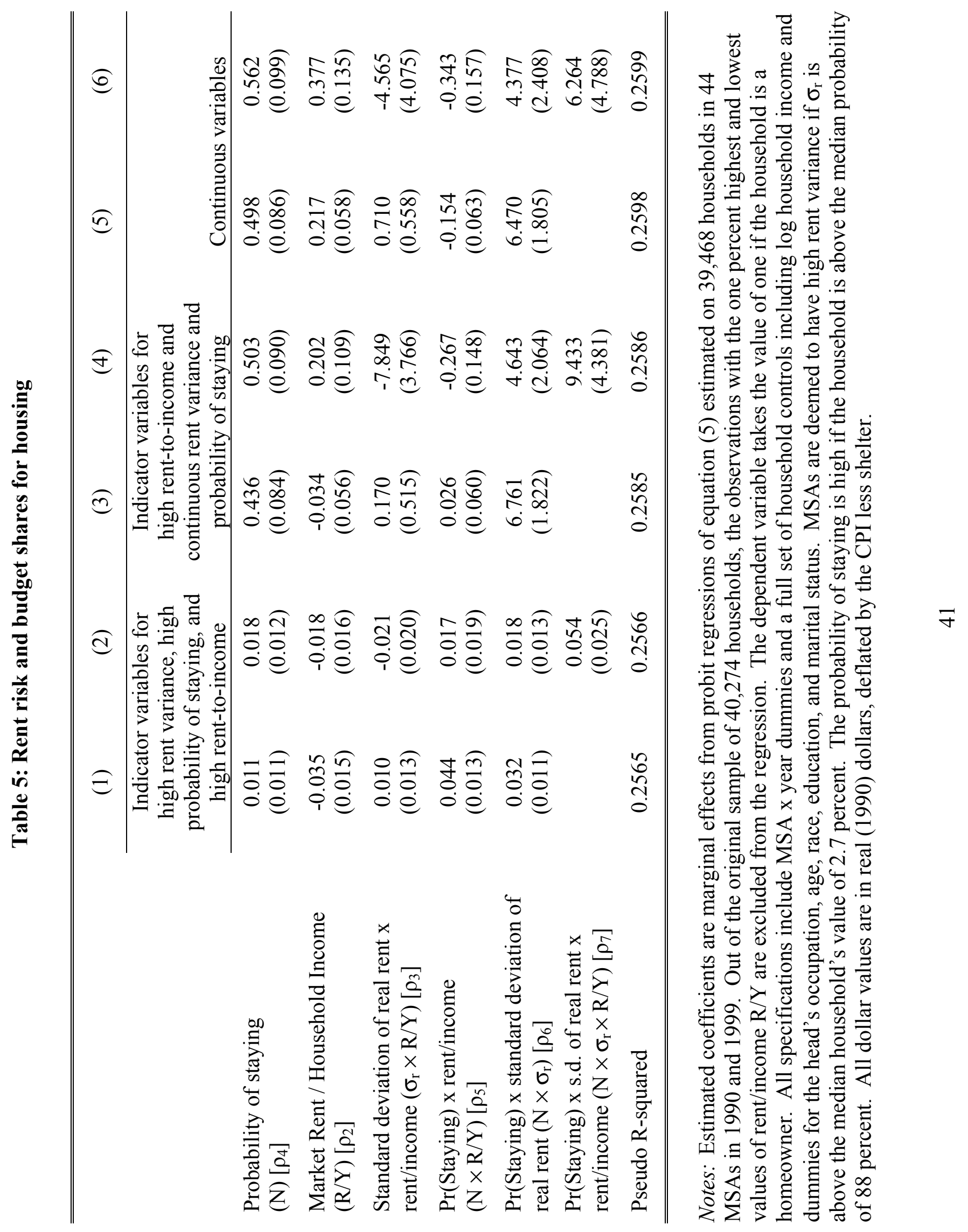


Table 6: The effect of rent risk on the price-to-rent multiple

\begin{tabular}{|c|c|c|c|}
\hline & (1) & (2) & (3) \\
\hline $\begin{array}{l}\text { Standard deviation of } \\
\text { real rent }\left(\sigma_{\mathrm{r}}\right)\end{array}$ & $\begin{array}{c}34.52 \\
(11.88)\end{array}$ & $\begin{array}{l}11.04 \\
(5.55)\end{array}$ & $\begin{array}{l}10.10 \\
(3.81)\end{array}$ \\
\hline Real rent growth & $\begin{array}{c}68.99 \\
(14.68)\end{array}$ & $\begin{array}{l}16.73 \\
(4.67)\end{array}$ & $\begin{array}{l}18.14 \\
(5.23)\end{array}$ \\
\hline $\begin{array}{l}\text { Controls for MSA fixed } \\
\text { effects? }\end{array}$ & No & $\begin{array}{c}\text { MSA } \\
\text { dummies }\end{array}$ & $\begin{array}{c}\text { First } \\
\text { differences }\end{array}$ \\
\hline Number of observations & 396 & 396 & 352 \\
\hline R-squared & 0.0486 & 0.9471 & 0.1609 \\
\hline $\begin{array}{l}\text { A one standard deviation } \\
\text { increase in } \sigma_{\mathrm{r}} \text { leads to... }\end{array}$ & $\begin{array}{c}0.62 \\
(0.21)\end{array}$ & $\begin{array}{c}0.20 \\
(0.10)\end{array}$ & $\begin{array}{c}0.18 \\
(0.07)\end{array}$ \\
\hline
\end{tabular}

Notes: Dependent variable is the price-to-rent ratio. Estimation is by OLS, following equation (6). Standard errors in parentheses. Number of observations equals 44 MSAs per year over the 19901998 time period. All specifications include year dummies. $\sigma_{\mathrm{r}}$ and real growth rates are computed based on the previous (rolling) nine years. A one standard deviation increase in $\sigma_{\mathrm{r}}$ is 0.018 (from a mean of 0.031 ). The average price-to-rent ratio is 15.72 . 


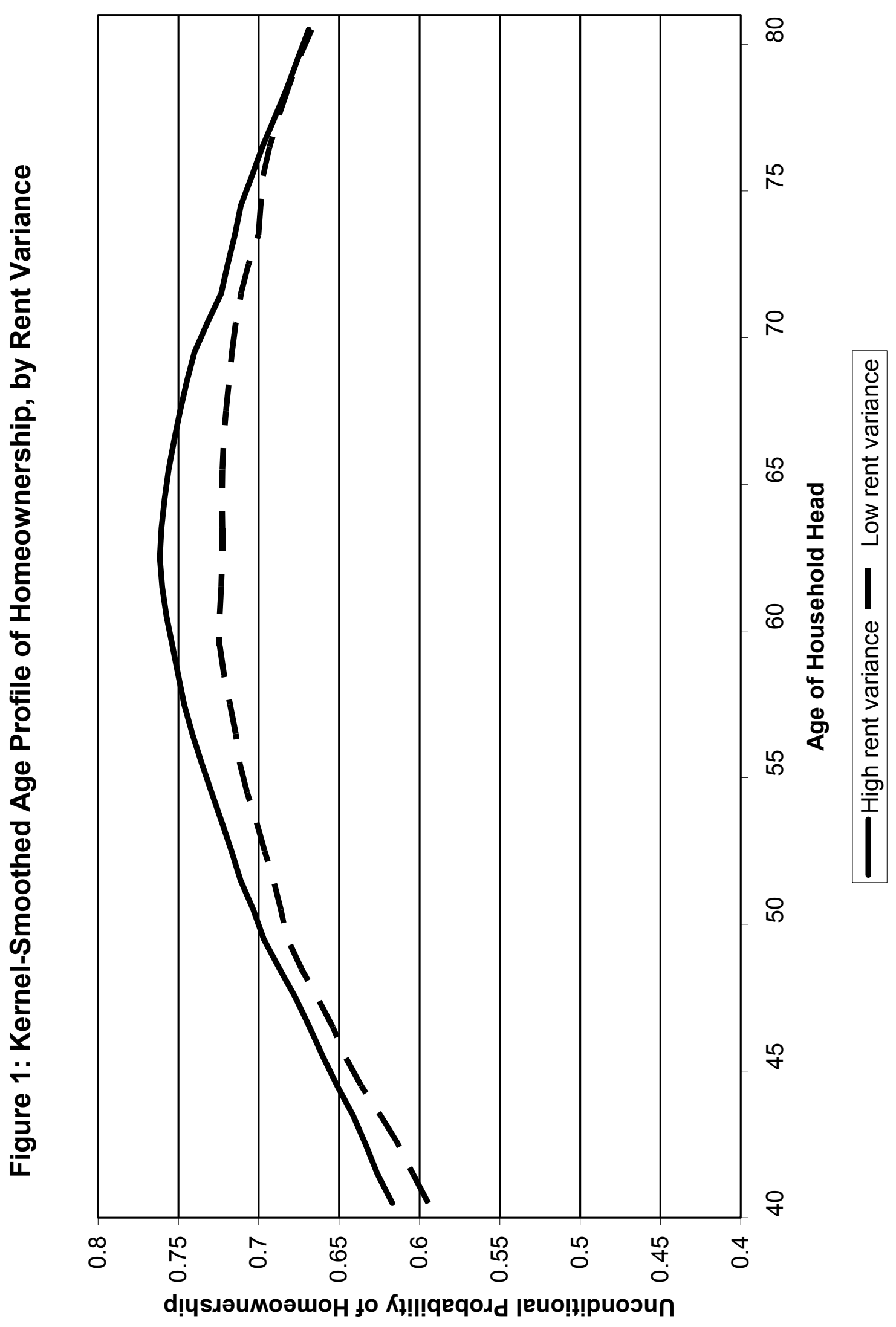

